\title{
The global war on terror, American foreign policy, and its impact on Islam and Muslim societies
}

\author{
Ahmad Fuad Fanani \\ Post-graduate student in the School of International Studies, Flinders \\ University, Australia; Researcher at the Center for the Study of Religion \\ and Civilization (PSAP) Muhammadiyah \\ E-mail:foead79@yahoo.com
}

\begin{abstract}
The global war on terror that was started after $11 / 9$ tragedy has continued until to date. The global war on terror not only shaped the new political balance in the international world, but also influenced the relationships between the U.S. and Western countries with Muslims countries and Muslims around the world. This is because the war on terror has positioned Islam and Muslims in negative image as the serious threat to the West. Many people stated that the $11 / 9$ tragedy is the evidence of "the clash of civilizations" between Islam and the West. As a result, some observers argue that the war on terror is the war against Islam based on the clash of civilizations thesis. However, others rebut this argument by explaining the facts that many Islamic countries supported to the war on terror. In fact, Islam has many schools of thought and cannot be understood in single understanding. Importantly, Islamic extremist movements are not the mainstream group in Muslims societies. This article will examine the relationship between the war on terror and the clash of civilizations thesis. It also assesses the Islamic world and Muslims response toward this agenda. It will argue that the war on terror is
\end{abstract}


not war against Islam, but the war against terrorist groups and radical Muslims which often hijacked Islam.

Perang global atas teror yang diprakarsai Amerika Serikat sebagai tanggapan terhadap tragedi 11 September 2011 terus berlanjut hingga hari ini. Diskursus ini tidak hanya memengaruhi keseimbangan politik dalam percaturan international, namun juga mempunyai dampak yang signifikan terhadap relasi antara Islam dan Barat. Hal ini karena Islam dan kaum Muslim ditempatkan pada posisi yang negatif dan menjadi ancaman nyata terhadap Barat. Berkaitan dengan itu, masyarakat banyak yang mempercayai bahwa tragedi 11 September adalah bukti nyata dari tesis "benturan peradaban" antara Islam dan Barat. Dalam hal ini, banyak pengamat juga meyakini bahwa the global war on terror adalah perang melawan Islam berdasarkan analisis benturan peradaban. Namun, sebagian pengamat membantah bahwa perang ini adalah perang melawan Islam dengan menunjukkan bukti banyak negara Muslim yang bergabung dengan agenda ini. Di samping itu, Islam juga mempunyai banyak mazhab pemikiran dan tidak bisa dipahami menjadi hanya satu pemahaman. Gerakan Islam ekstremis pun, tidak menjadi arus utama dalam masyarakat Islam. Artikel ini akan menganalisis hubungan antara the global ar on terror dan benturan antarperadaban. Juga akan dibahas respon dunia Islam dan masyarakat Muslim terhadap agenda global ini. Berkaitan dengan itu, artikel ini akan berargumen bahwa the global war on terror bukanlah perang melawan Islam, namun perang melawan teroris dan Muslim radikal yang seringkali membajak Islam.

Keywords: Global war on terror; Clash of civilizations; US foreign policy; Islamic world; Radical Muslims

\section{Introduction}

The war on terror campaign which was initiated by the United States after the horrific attacks on the World Trade Center (WTC) and Pentagon on September 11, 2001, have continued until today. The war on terror has emerged as the new vocabulary in the world politics and international relations which has influenced for the relationship between the US and other countries. This is because the attack caused significant impacts on the US foreign and defense policies toward other part 
of the world. According to Rizal Sukma, if terrorist attacks do not happen in the US, its effects would not have had huge impact worldwide. As a consequence, because the US is the superpower with global interest and global agenda, the other countries have to adjust to American foreign and defense policies with was issued after September $11^{\text {th }}$ tragedy. ${ }^{1}$

In this regard, Islam and Muslim societies have indirectly and directly affected by the war on terror agenda. The main reason for this is that the September $11^{\text {th }}$ tragedy has created a new world order in which Islam has become the centre of attention and suspicion. The tragedy also placed Islam in important position negatively than before. Some observers and ordinary people also stated that the September $11^{\text {th }}$ as the evidence of "the clash of civilizations" between Islam and the West which was predicted by Samuel Huntington one decade before. ${ }^{2}$ In fact, the attention and suspicion toward Islam was strengthened by Osama bin Laden and Al-Qaeda when they claim that they were responsible for the action. As we know, Al-Qaeda members consist from Muslims extremist who always campaign that American is the great enemy for Islam. As a result, Islam, especially its radical forms, has become a serious threat to the West and to international security and peace.

Regarding the above issue, some observers state that the war on terror is the war against Islam based on the clash of civilizations analysis, also the evidence from the American and Western double standard toward Muslim countries. However, some experts rebut this argument by providing reasons that the war against terror is not war against Islam. The reasons behind that are that many of Islamic countries

\footnotetext{
${ }^{1}$ Rizal Sukma, "War on Terror, Islam and the imperative of democracy", Asia Europe Journal, Springer-Verlag 2 (2004), 85.
} 
joined to the war on terror and Islam has many schools of thought. And Islamic extremism which was represented by Al-Qaeda and Osama bin Laden is only a small group in Islam and do not has enough support from Muslim mainstream. This essay will assess the relationship between the war on terror and the clash of civilizations thesis as well as the Islamic world responses toward the agenda. Particularly, the following questions will guide trajectory of this essay: Do the region's Muslims see the "War on Terror" as a war against Islam and the Islamic World? And, if so, why? In attempt to answer these questions, this article is divided into three sections. The first section examines the relevance Samuel P Huntington's clash of civilizations thesis to the war on terror agenda. The second section assesses Islamic world and Muslim countries responses toward the war on terror agendas. The third section elaborates the problem of radical Muslims and reevaluating the war on terror.

\section{The war on terror or the war against Islam?}

The terrorist attack on New York and Washington on 9/11/2001 became the iconic event because it is not only a new type of terrorist phenomenon but also its demands for all societies in many countries. For President George W. Bush and other national political leaders, these attacks showed a big crisis which brought to the emergence situations. Bush also called the 9/11 as 'the Pearl Harbor of the $21^{\text {st }}$ century' and after that immediately declared a global 'war on terror'.3 Because the US has big bargain position with its the hegemonic position in the world politic, its campaign for a global 'war on terror' also shaped for the

\footnotetext{
2 Rizal Sukma, "War on Terror", 87-88.

3 J.E. Owens and R. Pelizzo, "Introduction" in J.E. Owens and R. Pelizzo (eds.), The 'War on Terror' and the Growth of Executive Power? A Comparative Analysis, London: Routledge,2010, 3-4.
} 
foreign and domestic policies of many countries. As a result, they followed the Bush doctrine about the war on terror and did respond positively to the US. These countries strengthened their national and domestic security because they were the targets of terrorist attacks by Islamic extremists groups like Al-Qaeda and Jama'ah Islamiyah. ${ }^{4}$

Actually, some observers, intellectuals, politicians, and mass media in America state that $11^{\text {th }}$ September event was the proof of Huntington thesis about the clash of civilizations. As we know, in his article which was published in Foreign Affairs on Summer 1993 with title The Clash of Civilizations?, Huntington asserted that a 'clash of civilizations' will dominate global politics'. He contends that the future conflict will occur between the West and several Islamic-Confucian states. ${ }^{5}$ Huntington proofs his thesis by arguing that Islam and West are not close friend, but age-old enemies. The reason for this is that the conflict between Western and Islamic civilizations has happened for over 1300 years and continues until today. Indeed, the conflict between the West which was represented by America and the rest which was represented by Islam, made their both interactions is seen as clash of civilizations. ${ }^{6}$

Meanwhile, lots of political scientists in America and other countries commented to Samuel Huntington's thesis. Most of them do not believe Huntington's thesis and thought that it was trashed article. For example, they argued that the global politics was shaped and influenced by interests and states rather than culture or civilization. They also reveal that civilizations could not control states, but states control civilizations. ${ }^{7}$ However, when the attack of September 11 took place,

\footnotetext{
4 J.E. Owens and R. Pelizzo, "Introduction", 4-5.

${ }^{5}$ S. Huntington, "The Clash of Civilizations?", Foreign Affairs, Summer (1993), 27.

${ }^{6}$ S. Huntington, "The Clash of Civilizations?", 10.

7 E. Abrahamian, "The US media, Huntington, and September 11", Third World Quarterly, Volume 24, Number 3 (2003), 2.
} 
many of intellectuals, observers, and mass media in America immediately changed their opinion about Huntington's thesis. They stated September 11 with the context of Islam, culture and civilizations. Ervand Abrahamian points out that the mainstream media such as New York Times, Wall Street Journal, Washington Post, Time, Newsweek, Atlantic Monthly, New Republic, and some extent the Nation and the New York Review of Books, applied Huntington's thesis to September $11 .^{8}$ They framed that the Western civilization was threatened by the Other, namely Islam and Muslim communities. In this respect, Samuel Huntington states that Osama bin Laden has speeded the clash of civilizations. He also called the contemporary era as the 'Age of Muslim War'. ${ }^{9}$

It has been asserted that in the aftermath of the September $11^{\text {th }}$ terrorist attacks, President George W Bush and many policy makers often affirmed that the global war on terror was a war against terrorism, not against Islam. The program of visiting masques and dialogues with Islamic leaders was conducted to convince about Bush's administration campaign. However, America's hunt and action toward terrorism and organizations which was suspected as terrorism result to Muslim conviction that the war is indeed a war against Islam and Muslims. This conviction was also supported by the fact that Bush and the Pentagon at the early time of the war on terror used the terms 'crusade', infinite justice', and later used the code name 'the green front'. ${ }^{10}$ According to Esposito, the code name "the green front" indirectly tends to suspect Islam and Muslim. This is because the green is symbolic color of Islam. This code used by government official to storm Muslim

\footnotetext{
${ }^{8}$ E. Abrahamian, "The US media, Huntington, and September 11", 2.

${ }^{9}$ E. Abrahamian, "The US media, Huntington, and September 11", 4.

10 J.L. Esposito, Unholy War: Terror in the Name of Islam, Oxford: Oxford University Press, 2002, 13-14.
} 
organizations and homes in Northern Virginia and Georgia. ${ }^{11}$ In short, we can see that the Bush and his proponents try to convince Muslim believers about their different opinion on the war on terror. Otherwise, the realities in political arena and mass media clearly showed that the war on terror in some degrees was the war against Islam.

It is important to note that Osama bin Laden also strongly agree with the Huntington's thesis about the class of civilizations. This opinion can be read on Osama bin Laden announcement and fatwa (Islamic religious statement) in October 7, 2001. At this occasion, he said that September 11, "have divided the world into two sides -the side of believers and the side of infidels...Every Muslim has to rush to make his religion victorious. The winds of faith have come." In order to emphasize and wide its fatwa, Osama bin Laden delivered a speech at al-Jazeera television on November 3, 2001. In this event, he repeats his message by stating: "This is matter of religion and creed, it is not what Bush and Blair maintain, that it is a war against terrorism. There is no way to forget the hostility between us and the infidels. It is ideological, so Muslims have to ally themselves with Muslims". As a result, it is not surprise when T.E. Lawrence states that Bin Ladin is the real dangerous man in the world today. He also repeatedly conveyed that al Qaeda is the fundamental raison d'entre behind strengthening the terms of the 'clash of civilizations.'12

Meanwhile, Osama bin Laden's view about September 11 tragedy which was presented in the above clearly shows that he and Al-Qaeda group have stood in the same position with the American people who thought September $11^{\text {th }}$ was the evidence of the clash of civilizations. The proponent of the clash of civilizations thesis in America also cite

\footnotetext{
11 J.L. Esposito, Unholy War: Terror in the Name of Islam, viii.

${ }^{12}$ B. Hoffman, Inside Terrorism, New York: Columbia University Press, 2006, 93.
} 
Osama bin Laden and Al-Qaeda as clear facts of-borrowing John L Esposito words-an unbridgeable gap between two very different world. Likewise, the presence religious extremist groups and terrorist which declared the war against America and the West, also cited by the proponent of the clash of civilization that Islam is not compatible with democracy and continue to make conflict with the West. ${ }^{13}$ This fact can be seen as the parallel between two groups who have a close view about the position of religion as the justification of their political actions. Both of Osama bin Laden-Al-Qaeda and the 'neo-con's' group which dominated the Bush Administration seemed to identify the war on terror based on the clash of civilization thesis. They looked to simplify the problem, instead of questing and analyzing deeply to the roots, the case, and the alternative solutions to combating terrorism.

Although applying the clash of civilizations thesis as the tool analysis to understand for the September $11^{\text {th }}$ was very simplistic, this point of view was very popular on Bush administration. As Michael Sullivan notes, the 'neo-cons' have important position politically and they playing a crucial role in Bush Administration response toward September $11^{\text {th }}$. This response later was known as Bush Doctrine. As a result, although the public reluctance try to avoid the words 'clash of civilizations' as strategy to prevent Muslim fear, the 'neo-cons' disregard this fact. In contrast, the 'neo-cons' developed the Global War on Terror with a strong religious commitment as Christian crusading purpose. Consequently, when Al-Qaeda issued fatwa and suggested jihad against the West, there were many people in the West called for a 'crusade against Islam'. ${ }^{14}$ In addition, John L Esposito also shows that the alliance be-

\footnotetext{
13 J.L. Esposito, Islam and the West after September 11: Civilizational Dialogue or Conflict?, Abu Dhabi: The Emirates Center for Strategic Studies and Research, 2002, 12.

${ }^{14}$ M. Sullivan, "Topic Introduction on ASST 3046 The War on Terror: A Clash of Civilizations?", unpublished paper, Faculty of Behavioral and Social Sciences, Flinders University, Adelaide, 5.
} 
tween the Christian Right and Republican neo-conservatives who support this agenda with a theological/ideological pro-Israel Zionist interests, intensify this bad situation. Besides that, their call for targeting of 'terrorist' states, from Libya, Sudan, Iran, Iraq, and Syria, encourage confirmation to those who perceive the hidden agenda behind the war on terror. ${ }^{15}$

Furthermore, as Rizal Sukma states, when the American-led war on terror did not stop in Afghanistan, inharmonious relationship between the Muslim world and the West (particularly the US) widened. The invasion of Iraq, the inclusion Iran into "the Axis of Evil" and other agendas of "the war on terror" in US policy, triggered the emergence opinions and thoughts from Muslim people and many educated persons that the centre of American war on terror is Islam. ${ }^{16}$ As a result, Muslim societies saw that the war on terror is a thinly disguised war against Islam. This condition also supported by the facts about the using a double standard tendency in American foreign policy toward Islamic world and Muslim societies. For example, in dealing with IsraeliPalestine conflict, the U.S. strongly favored to Israel and call Palestine people as "Palestinian terrorism". The Bush administration also criticized and demanded the Palestine's leaders for suicide bombing, but praised Israeli's leaders as the man of peace. Indeed, America also often used its military and political power unilaterally, disproportionately and indiscriminately when dealing with conflicts which involved Islam such as in Palestine-Israel, India-Pakistan, and Russia-Chechnya. ${ }^{17}$ Consequently, some of Muslim societies assumed that the war on terror not just against terrorism and religious extremists but also against Islam and the Muslim world.

\footnotetext{
15 J.L. Esposito, Islam and the West after September 11, 17.

${ }^{16}$ Rizal Sukma, "War on Terror", 88.

17 J.L. Esposito, Unholy War, 154-155.
} 


\section{Islamic world responses toward the war on terror}

It is clear that Muslim societies and Islamic countries have condemned the terrorists who have killed many civilians at the tragedy September $11^{\text {th }}$. They are also condolence for the victims of the $9 / 11$ terrorist attacks. Indeed, some of the Islamic countries supported when the America-led war against terror invaded the Taliban regime in Afghanistan which was unwilling to surrender Osama bin Ladin to the US. In contrast, although a majority of Muslims in Southeast Asia did not approve of Taliban and Osama bin Laden interpretations of Islam, they saw that the attack of Afghanistan as an attack on Islamic nation, and some degrees also an attack to Islam. As a consequence, even though the Western leaders always campaign that Islam was not the target on the war on terror, most of Muslims in Southeast Asia do not believe it. ${ }^{18}$ This situation has become more unclear because the widespread and extensive bombing of Afghanistan caused the innocent Afghan people as victims. Because of the strong public protest in Jakarta and Kuala Lumpur, Indonesia and Malaysia government decided to refrain from openly supporting the US-led coalition in the war against Afghanistan. ${ }^{19}$

Due to the U.S. response to the attack of September 11 by invading Afghanistan, sympathy and solidarity for the victims of September 11 changed immediately to anger and fear. Many Muslims in Indonesia, Malaysia, Thailand, and Philippines conveyed that the attack on Afghanistan was widely perceived as unjust, brutal, and damaged on innocent people. It is interesting to note that many of moderate Muslims in Indonesia which was represented by Nahdlatul Ulama' (NU),

${ }^{18}$ B. Adeney-Risakotta, "The Impact of September 11 on Islam in Southeast Asia", in K.S. Hathan and M.H. Kamali (eds.), Islam in Southeast Asia: Political, Social and Strategic Challenges for the $21^{\text {st }}$ Century, Singapore: Institute of Southeast Asian Studies, 2005, 325.

${ }^{19}$ R. Sukma, "War on Terror", 88. 
Muhammadiyah, and Majelis Ulama Indonesia (MUI) joined with more radical Muslim groups to condemn the U.S. attack on Afghanistan. At that occasion, it can be seen that the anger against American unilateral militarism was placed at higher degree than the anger against terrorism. ${ }^{20}$ In relation to the American attacks on Afghanistan and Iraq, we can refer to the definition of terrorism that means a violent attack against innocent people which was done by individuals or groups for a larger political purpose. By referring this definition, many Muslim argued that U.S bombing in Iraq and Afghanistan or Israel attacks on Palestinian as terrorist because of the high number of civilian victims. ${ }^{21}$

Meanwhile, Muslim states response toward the war on terror was varied, it depend on the internal condition of the country and its relations with the United States. Pakistan is the country which stands in front of America and support fully for the U.S. agenda on the war on terror. It has been noted that September 11 has brought Pakistan as central to the US-led coalition against terrorism. The geographic strategic position of Pakistan where was very close to Afghanistan encouraged the Pakitanis leaders for using the war on terror as the tactic to reduce its internal problem. The economic bankruptcy, implosion, and diplomatic isolation which were suffered by Pakistan suddenly changed to become political support and economic support from major states after its joining with this global agenda. ${ }^{22}$ However, the government decision to make alliance with the US do not gain enough support from the people. Many of Islamic groups in Pakistan state that the benefit of the alliance only for the "colluder", and the Pakistani people was

${ }^{20}$ B. Adeney-Risakotta, "The Impact of September 11 on Islam in Southeast Asia", 326-327.

${ }^{21}$ B. Adeney-Risakotta, "The Impact of September 11 on Islam in Southeast Asia", 334.

${ }^{22}$ S. Yasmeen, "Unexpectedly at Center Stage, Pakistan" in Mary Buckley and Rick Fawn (eds.), Global Responses to Terrorism: 9/11, Afghanistan and Beyond, London: Routledge, 2003, 189. 
used as the legitimacy. The Bush's identification of Iran and Iraq as part of "the axis of evil" and Afghanistan invasion was seen by Pakistan people as the anti-Muslim globally. As a consequence, the support of Pakistan government toward the war on terror triggered the rising number of Islamist in Pakistan who oppose to its government and America. ${ }^{23}$ And for the United States, Pakistan has become both part of the problem and part of the solution. The main reason for this is that, Pakistan is ally in the war against terrorism, but at the some time Pakistan appears as a potential base of Islamic radicalism groups who hate America. ${ }^{24}$

The position of Saudi Arabia in the war on terror actually was almost similar with Pakistan. This is because this country has role in the growth of Al-Qaeda during the occupation of Afghanistan in 1980s and in the rising of Sunni Muslim extremism which inspired by the Wahhabism. Many people in the US saw that Al-Qaeda and Wahhabism have a close correlation by way of using violence in their religious understanding. As a consequence, the terrorist groups which often apply religious text as their justification for attacking the innocent people, directly was associated with both Al-Qaeda and Wahhabism. However, as point out by F. Gregory Gause III, the tragedy of September 11 and Riyadh bombing in 2003 has changed the Saudi authorities to aware the threats of Sunni Muslim extremism and consider the strategy to prevent it. Then, the Saudi joined the war on terror agenda and the Bush administration sending a team of senior counterterrorist to press Saudi. As a result, Saudi government declared its new policy to investigate the charity organization which support Muslim extremist. Besides that, the

${ }^{23}$ S. Yasmeen, "Unexpectedly at Center Stage, Pakistan", 199.

${ }^{24}$ S.P. Cohen, "The Jihadist Threat to Pakistan" in James F. Hoge Jr \& Gideon Rose (eds.) Understanding the War on Terror, New York: Council of Foreign Relations, 2005, 221. 
Saudi government intends to stop providing diplomatic status for Islamic clerics and educators who will preach to other countries. ${ }^{25}$ Interestingly, leading religious officials of Saudi Arabia such as the Higher Council of Ulama also condemned the terrorist attacks and make official statement that rejected bin Laden's interpretation of jihad. ${ }^{26}$

It is important to note the response of Afghanistan, Iran, and Iraq on the war on terror agenda. As we know, these countries were led by the leaders who always oppose and criticize the American double standard to Islamic world. In fact, it was not surprising when Aiman alZawahiri, al-Qaeda deputy in Afghanistan stated that the tragedy of September 11 was the result of the American actions which often invaded Islamic states. Similarly, Iranian President, Mahmoud Ahmadinejad also sent a letter to President Bush admonishing its wrong decision about the war on terror. Therefore, Ahmadinejad denied to join the war on terror due to his believe that the America was the sponsor of international terrorism in Israel. Then, Iran tried to convince other countries that the fall of the United States, of Israel, and Zionism is possible goal and slogan by referring its success on the Islamic Revolution in 1979.27 At the same time, Iraq government and people faced the difficult situation because had been consistently accused by America as the forefront of supporting terrorism and developing WMD capabilities. And the US has made a final decision to overthrow the regime under Saddam Husein which has been realized in $2003 .{ }^{28}$

${ }^{25}$ F.G. Gause III, "Saudi Arabia and the War on Terror", in James F. Hoge Jr \& Gideon Rose (eds.) Understanding the War on Terror, New York: Council of Foreign Relations, 2005, 227-228.

${ }^{26}$ F. G. Gause III, "Saudi Arabia and the War on Terror", 229.

27 J. Kelsay, Arguing the Just War in Islam, Cambridge: Harvard University Press, 2007, 204207.

${ }^{28}$ R. Dannreuther, "Radical Islamist State and Secular Arab Nationalism: Iran and Iraq" in Mary Buckley and Rick Fawn (eds.), Global Responses to Terrorism: 9/11, Afghanistan and Beyond, London: Routledge, 2003, 132-133. 
Furthermore, it is interesting to underline the response of Muslim countries in Southeast Asia (Indonesia, Malaysia, Thailand, and the Philippines). This is because the US has decided the Southeast Asia as the important front on the war on terror immediately after the 9/11 attack. In this case, Indonesia, Malaysia, and the Philippines were reportedly named by the U.S. State Department as "potential Al-Qaeda hubs". Then, the arrest of dozens al-Qaeda members in these countries suggested the designation of Southeast Asia as the Second Front on the war on terror. ${ }^{29}$ Actually the first response of Southeast Asia countries about the war on terror was not clear. They condemned the 11 September attack and also condemn the U.S. attack against Afghanistan. However, after the recent facts about the existence of AlQaeda networks in Southeast Asia, the governments of these countries have changed their attention to the challenge posed by Muslim radical groups. ${ }^{30}$ As a consequence, most of these countries have supported the war on terror agenda.

In this respect, Malaysia Government which was led by Prime Minister Mahathir Mohamad got many benefits from the joining of the war on terror to reclaim his positive image toward America. The position of Mahathir actually ambiguous, on the one side he defended his reputation as Muslim leader by criticizing the Western attack on Afghanistan, but on the other side he also strongly condemned the 9/11 and arrested Islamic radical members who opposed its government. ${ }^{31}$ Meanwhile, the Thailand Government response toward the war on terror

\footnotetext{
${ }^{29}$ R. Sukma, "War on Terror", 88-89. Also see, John Gersman, "Is Southeast Asia the Second Front?" in James F. Hoge Jr \& Gideon Rose (eds.) Understanding the War on Terror, New York: Council of Foreign Relations, 2005, 234.

${ }^{30}$ B. Desker, Islam and Society in Southeast Asia After September 11, Singapore: Institute of Defence and Strategic Studies Working Paper series, 2002, 1.

${ }^{31}$ B. Adeney-Risakota, "The Impact of September 11 on Islam in Southeast Asia", 338.
} 
was influenced by its bad relations with Islamic groups in the country. Since the 1960s, the Malay Muslim who lived in Thailand campaigned for independence and the Government perceived this demands by assimilation, repression, and accommodation policies. In fact, the war on terror has strengthened the cooperation with Malaysia, Singapore, and Indonesia in searching out terrorists in its region. Besides that, the Thai Government also used this agenda to dealing harshly with radical dissidents. ${ }^{32}$ Due to the position as the closest ally to the U.S. in Southeast Asia, the Philippines has offered the most comprehensive backing for the war on terror. President Gloria Macapagal Arroyo, different with other countries in this region, also supported the U.S. attack on Afganistan and proposed the use of the Philippines as the military bases. Besides that, the war on terror also intensified the Philippines Government conflict with Muslim Southeast Asia which formed the Moro Islamic Liberation Front (MILF). ${ }^{33}$

It has been argued that Indonesia response toward the war on terror agenda was various. In the immediate aftermath of 9/11 most of Indonesian people and the Government revealed sympathy to the victims. In contrast, when the U.S. invaded Afghanistan and Iraq, they strongly criticized. Some people and politicians also stated that $9 /$ 11 actually the kind of conspiracy of US and Israel to against Muslim world. However, Bali bombing in 2002 and subsequent bombings after that brought a real shift in public perceptions toward the war on terror and Islamic radical groups. ${ }^{34}$ In fact, the Indonesian Government has

32 B. Adeney-Risakota, "The Impact of September 11 on Islam in Southeast Asia", 339-340.

33 B. Adeney-Risakota, "The Impact of September 11 on Islam in Southeast Asia", 340-341.

${ }^{34}$ See, E.V. Schneier, "Reformasi and the Indonesia 'War on Terror': State, Military and Legislative-Executive Relations in an Emerging Democracy", in J.E. Owens and R. Pelizzo (eds.), The 'War on Terror' and the Growth of Executive Power? A comparative Analysis, London: Routledge, 2010, 229. 
called experts from Western countries, including the American Federal Bureau of Investigation (FBI), to find the terrorist who responsible for the bombings. This action would have been made before the Bali bombing, even though President Megawati symbolically accepted Bush's invitation to join the 'war on terror' in 2001. In order to prevent the terrorist attack to its people, the Indonesian government also proposed counter-terrorism legislation and issued executive orders to arrest suspected terrorists. Additionally, Megawati government also accepted funds from the U.S. to cooperative intelligence and participate in counter-terrorism activities. ${ }^{35}$ At this point, Rizal Sukma asserted that the Bali Bombing became a solid proof of imminent threats from Islamic radicalism. Although there are only a few Muslims who are radicals, but the threat of terrorism from this group who advocate violence is real. ${ }^{36}$

\section{The problem of radical Muslims and reevaluating the war on terror}

In terms of both religious doctrine and tradition, Islam can be interpreted from two perspectives: radical/fundamentalist and liberal/moderate. On the one hand, radical/fundamentalist Muslim groups often claim that Islam is not compatible with democracy, the West, and other contemporary thinking. This is because they understand Islamic tenets by using the textual method, rigid, closed dialogue, and with a purpose to build the Islamic state. On the other hand, liberal/moderate Islam argues that Islam has many general concepts which endorse the implementation of democracy in the Muslim world. They use the rational and contextual method, which is very important to interpret, and to understand God's purpose as stated in the Quran.

35 B. Adeney, "The Impact of September 11 on Islam in Southeast Asia", 339. Also see, Edward V. Schneier, "Reformasi and the Indonesia 'War on Terror", 229-232.

${ }^{36}$ R. Sukma, "War on Terror", 90. 
In this regard, Muslim attitudes toward the September 11 tragedy also can be divided into two categories. Firstly, moderate Islamists, they advocate Islam as dynamic ideology of political and social transformation. They also reject any form of violence and criticize the authoritarian regime. They regard that the September 11 provided many reason for the US and its allies to expand and deepen their dominance in the Muslim world by using the higher moral ground. Indeed, they contends that Osama bin Laden and al-Qaeda's action only brought negative implication for Muslim world that become victim of its negative attitudes. Secondly, radical Islamist, they regard the United States as the most dangerous enemy because of the U.S. policy for backing Israel and supporting dictatorial regimes in many Muslim countries. They believe that the international crisis since September 11 has been fuelled by deliberate strategy of pro-Israeli and Christians right in the Bush administration which desire to widen American global domination. ${ }^{37}$

It is also important to note that the 11 September 11 , has led to the radicalization of certain individuals and Muslims groups in Muslim countries, particularly in Indonesia. The rise of radicalism among Muslims appeared soon after the American military operation in Afghanistan. This invasion has given momentum to the radicals to assert themselves and to persuade others Muslim. Unfortunately, the American attack to Iraq has further fuelled the rising number of the radical Muslim. ${ }^{38}$ Then, many suicide bombing such as in Bali, Australian Embassy at Jakarta, Mariot, London, and others has proved that the terrorist tendencies amongst radical Muslim around the world. By con-

\footnotetext{
${ }^{37}$ A. Saikal, "Islam and the West: Containing the Rage?" in Shahram Akbarzadeh \& Samina Yasmen (eds.), Islam and the West: Reflections from Australia, Sydney: UNSW Press, 2005, 1618.

${ }^{38}$ A. Azra, "Militant Islamic Movements in Southeast Asia: Socio-Political and Historical Contexts", Kultur, the Indonesia Journal for Muslim Cultures, Volume 3, Number 1 (2003), 18.
} 
sidering these facts, many Muslim governments with Muslim societies supports, understood that radical Islamist is the real problem which has to solve soon by developing coherent antiterrorism policies.

Interestingly, many of Islamic leaders in Muslim country such as Indonesia, can be categorized into moderate group. The statement from National Chairman of Nahdhatul Ulama and National Chairman of Muhammadiyah in the aftermath of September 11 tragedy clearly stated that Indonesia Islam can not accept any kind of religious extremism or radical Islam. They also conducted many program and policies which was made to prevent the proliferation radical Islam in Indonesia. ${ }^{39}$ Hence, the view that Islam and terrorism are similar is wrong concept which based on a misperception that Islam can be generalized into one category only.

Moreover, although Osama bin Laden wrote in his fatwa that Muslims have to "kill the Americans and plunder their possessions wherever he finds them and whenever he can" 40 , he failed to gain supports from majority Muslims in the world. According to John L Esposito, his failure to mobilize the majority of 1,2 billion Muslims or the majority of Islamic leaders in his unholy war, is the proof that Muslims are indeed diverse. Islamic history also clearly showed that mainstream Islam always rejected or marginalized extremist and terrorist, from the past groups like Kharijites to contemporary movements like Al-Qaeda. ${ }^{41}$ Therefore, this fact and historical evidence should be used by the US in dealing with Islamic world. If they conducted and learned seriously about the varieties of Muslims attitudes, they can consider the wrong decision

${ }^{39}$ A. Azra, "Militant Islamic Movements in Southeast Asia: Socio-Political and Historical Contexts", 25-26.

40 J. Roshandel and S. Chadha, Jihad and International Security, New York: Palgrave Macmillan, 2006, 2.

${ }^{41}$ J.L. Esposito, Islam and the West, 13. 
such as attacking Afghanistan and Iraq in order to combat terrorism.

Inevitably, terrorism is a perennial phenomenon and ceaseless struggle. Even though the war on terror often practiced wrongly and unpopularity due to the wrong decision of the US to attack Afghanistan and Iraq, war by definition has to continue. The struggle against terrorism is never-ending due to terrorism has existed for 2.000 years and used many methods to perform its actions. As a consequence, efforts which have to do against terrorism must be as diligent, innovative, and dynamic. ${ }^{42}$ Thereby, America and its allies responses should be proportionate and based on justice, from military strikes and foreign policy to domestic security measures and create antiterrorism legislation. Besides that, the U.S must reexamination and reformulation its foreign policy toward Islamic world which often biased and triggered to the emerging of radical Muslims. ${ }^{43}$ If the American foreign policy issues are not refine and renew, it will be used by Osama bin Laden and its allies to provoke Muslims for widening anti America sentiment.

Because terror and Islamic radicalism are the real threat which faced by many countries around the world, it is better if the West and Islamic world build cooperation against Islamic radicalism and terrorism. In fact, for the success this effort, the U.S. and the West have to clearly distinguish between the "hijacking" of Islam by radical Muslims and terrorist groups with moderate Muslims who support the dialogue and cooperation with the West. In this respect, Western powers need to rethink and reassess their policies which often generalize Islam in one category. ${ }^{44}$ By cooperating and build a joint effort, the future world which more peace and tolerance can be realized.

${ }^{42}$ B. Hoffman, "Rethinking Terrorism and Counterterrorism Since 9/11", Studies in Conflict and Terrorism, 25 (2002), 314.

43 J. L. Esposito, Unholy War, 156-157.

${ }^{44}$ J.L. Esposito, Islam and the West, 24-26. 


\section{Conclusion}

This article has discussed the war on terror and its implication for Islam and Muslim societies. It has suggested that the September 11 tragedy was responded seriously by American and its allies also Islamic world. The 9/11 tragedy has confirmed some intellectuals, Bush administration and Muslim societies toward the clash of civilizations thesis. The main reason for this is that mainstream media in America was dominated by editorial and opinion from experts who agree with Samuel Huntington thesis. Besides that, Bush Administration who also used the religious term such as "crusade" and the "green front" in the war on terror, was seen by Muslims as the indirectly war against Islam. American attacks on Afghanistan and Iraq and American foreign policy toward Islamic states which often applied double standard approach, also increase the assumption about the war on terror is the war against Islam.

However, it can be argued from the above explanations that the Muslim responses toward the war on terror are varied. The responses depend on their Muslim adherent attitudes and the condition in certain country. Many Islamic states in Middle East states rejected to joining the war on terror agenda, instead of that they campaign that America is the main sponsor of international terrorism. Some governments used the war on terror as their strategy to stop the opponent from Muslim groups. And others applied the war on terror agenda as the policy to prevent its people from the Islamic radicalism group such as in Indonesia. The rising of Islamic radicalism groups in many Islamic countries in some degree is the result of the American foreign policy which attacks Afghanistan and Iraq. Therefore, Muslim moderate groups in Indonesia and Southeast Asia support their government policy in joining the war on terror as preventing the threat of Islamic radicalism and terror- 
ism. As a result, the war on terror actually not the war against Islam, but the war against terrorist groups which often hijacked Islam.

\section{Bibliography}

Abrahamian, E., "The US media, Huntington, and September 11", Third World Quarterly, Volume 24, Number 3 (2003): 529-544.

Adeney-Risakotta, B., "The Impact of September 11 on Islam in Southeast Asia", in K.S. Hathan and M.H. Kamali (eds.). Islam in Southeast Asia: Political, Social and Strategic Challenges for the $21^{\text {st }}$ Century. Singapore: Institute of Southeast Asian Studies, 2005.

Azra, A., "Militant Islamic Movements in Southeast Asia: Socio-Political and Historical Contexts", Kultur the Indonesia Journal for Muslim Cultures, Volume 3, Number 1 (2003): 17-27.

Esposito, J.L. Unholy War: Terror in the Name of Islam. Oxford: Oxford University Press, 2002.

Esposito, J.L. Islam and the West after September 11: Civilizational Dialogue or Conflict? Abu Dhabi: The Emirates Center for Strategic Studies and Research, 2002.

Cohen, S.P., "The Jihadist Threat to Pakistan", in James F. Hoge Jr \& Gideon Rose (eds.). Understanding the War on Terror. New York: Council of Foreign Relations, 2005.

Dannreuther, R., "Radical Islamist state and secular Arab Nationalism: Iran and Iraq", in Mary Buckley and Rick Fawn (eds.). Global Responses to Terrorism: 9/11, Afghanistan and Beyond. London: Routledge, 2003.

Desker, B. Islam and Society in Southeast Asia After September 11. Singapore: Institute of Defence and Strategic Studies Working Paper series, 2002. 
Gause III, F.G., "Saudi Arabia and the War on Terror", in James F. Hoge Jr \& Gideon Rose (eds.). Understanding the War on Terror. New York: Council of Foreign Relations, 2005.

Gersman, J., "Is Southeast Asia the Second Front?", in James F. Hoge Jr \& Gideon Rose (eds.) Understanding the War on Terror, Council of Foreign Relations, New York, 2005.

Huntington, S., "The Clash of Civilizations?", Foreign Affairs, Summer (1993): 22-49.

Hoffman, B. Inside Terrorism. New York: Columbia University Press,2006. Hoffman, B., "Rethinking Terrorism and Counterterrorism Since 9/11", Studies in Conflict and Terrorism, 25 (2002): 303-316.

Kelsay, J. Arguing the Just War in Islam. Cambridge: Harvard University Press, 2007.

Owens, J.E. and R. Pelizzo, "Introduction", in J.E. Owens and R. Pelizzo (eds.). The 'War on Terror' and the Growth of Executive Power? A Comparative Analysis. London: Routledge, 2010.

Roshandel, J. and Chadha, S. Jihad and International Security. New York: Palgrave Macmillan, 2006.

Saikal, A., "Islam and the West: Containing the Rage?", in Shahram Akbarzadeh \& Samina Yasmen (eds.). Islam and the West: Reflections from Australia. Sydney: UNSW Press,2005.

Schneier, E.V., "Reformasi and the Indonesia 'War on Terror': State, Military and Legislative-Executive Relations in an Emerging Democracy", in J.E. Owens and R. Pelizzo (eds.). The 'War on Terror' and the Growth of Executive Power? A Comparative Analysis. London: Routledge, 2010.

Sukma, R., "War on Terror, Islam and the imperative of democracy", Asia Europe Journal, Springer-Verlag 2 (2004): 87-93. 
Sullivan, M., "Topic Introduction on ASST 3046 The War on Terror: A Clash of Civilizations?", unpublished paper, Faculty of Behavioral and Social Sciences, Flinders University, Adelaide, 1-48.

Yasmeen, S., "Unexpectedly at Center Stage, Pakistan", in Mary Buckley and Rick Fawn (eds.). Global Responses to Terrorism: 9/11, Afghanistan and Beyond. London: Routledge, 2003. 